\section{REDISCOVERY OF BUFO MACROTIS BOULENGER (AMPHIBIA: ANURA) IN ARUNACHAL PRADESH, INDIA}

\author{
Mohini Mohan Borah ${ }^{1}$ and Sabitry Bordolo ${ }^{2}$ \\ ${ }^{I}$ Chaiduar College, Gahpur, District-Sonitpur, Assam, India. \\ ${ }^{2}$ P.O. Box No. 83, GPO, Guwahati, Assam 781001, India.
}

Arunachal Pradesh $\left(26^{0} 28^{\prime}-29^{\circ} 31^{\prime} \mathrm{N}\right.$ and $\left.90^{\circ} 30^{\prime}-97^{\circ} 30^{\prime} \mathrm{E}\right)$ is the home of many endemic and non endemic species of amphibia. Due to the difficult hilly terrain and lack of communication network, many parts of the state have remained unexplored or underexplored for amphibian faunal diversity. A toad Bufo macrotis, collected from East Kameng District has been recorded for the second time from Arunachal Pradesh from a district located in the far west. Earlier Boulenger (1890) reported this frog from various places in upper Burma (Myanmar).

Distinctive Characters: The specimens were collected by M.M. Borah from the bank of Khari River in the East Kameng District $\left(27^{\circ} 21^{\prime} 48^{\prime \prime} \mathrm{N}\right.$ and $93^{\circ} 3^{\prime} \mathrm{E}$ at Seppa, altitude $2317 \mathrm{~m}$ ) of Arunachal Pradesh. Taxonomic description was compared with Boulenger (1890) and Dubois (1999). Live coloration of the frog is grey brown on the dorsal side whereas ventral side is creamy white without any markings. Cross bands present on the limbs. Pupil horizontal, tongue entire, terminal phalanges obtuse. Skin rough and tubercular. Elevated bony ridges are absent but very low ridges can be identified. Short interorbital space flat as broad as upper eyelid. Tympanum very close to eye, distinct and vertically oval. Detailed morphometric measurements have been presented in Table 1. Relative length of fingers $3>1>2>4$. Toes half webbed without prominent subarticular tubercles but full of irregular tubercles. Relative length of toes $4>3>5>2>1$. Outer metatarsal tubercle is bigger than inner metatarsal tubercle. Tibio tarsal articulation reaches shoulder. Parotid glands prominent $(6 \mathrm{~mm})$.

Male is smaller than the female. Throat of the male is blackish. One subgular vocal sac is present. Two inner fingers have black rugosities. Upper surface of the thumb has a black keratinised structure, the nuptial pad.

Boulenger (1890) recorded Bufo macrotis from Bhamo, Teinzo and Kakhyen Hills, upper Burma. Since the description of Boulenger (1890), Sarkar and Sanyal (1985) recorded a dam- aged specimen from Namdapha (proposed) Biosphere Reserve. Inger (1972) included this species in the Bufo biporcatus group. Dubois and Ohler (1999) is also of the opinion that Bufo macrotis and Bufo parvus Capocaccia (1957) are closely related. Dutta (1997) mentions this species in the doubtful category. Since the record of the damaged specimen by Sarkar and Sanyal, the present description is the first report of a male and female from this region. The present description has been compared with Boulenger (1890) and no difference was noted.

\section{Acknowledgement}

Authors acknowledge the help of Dr. S.K. Dutta, Utkal University, Bhubaneswar for confirmation of the identification of the specimens and are also grateful for the financial assistance of the G.B. Pant Institute of Himalayan Environment and Development, Kosikatarmal, Almora, Uttaranchal, India .

\section{References}

Boulenger, G.A. (1890). The Fauna of British India, including Ceylon and Burma. Reptilia and Batrachia. Taylor and Francis, xviii+541 pp. London.

Capocaccia, L. (1957). Catalogo Dei Tipi di Anfibi Del Museo Civico di Storia Naturale di Genova. Estr, Dagli. Annal.Del Museo.Civic. di stor. Natur. df Genova. 69: 208-222.

Dubois, A. and A. Ohler (1999). Asian and Oriental toads of the Bufo melanostictus, Bufo scaber and Bufo stejnegeri groups (Amphibia, Anura); a list of available and valid names and redescription of some name-bearing types. Journal of South Asian Natural History, 4(2): 133-180.

Dutta, S.K.. (1997). Amphibians of India and Sri Lanka (Checklist and Bibliography). Odyssey Publishing House, Bhubaneswar.

Inger, R.F. (1972). Bufo of Eurasia, pp. 102-118. In: Blair, W.E., Editor. Evolution in the genus Bufo. University of Texas Press, Austin and London.

Sarkar, A.K. and D.P. Sanyal (1985). On a collection of amphibia from Namdapha National Park, Tirap District, Arunachal Pradesh. Record of Zoological Survey of India 82(1-4): 285-295.

Table 1. Morphometric measurements of the specimens.

\begin{tabular}{lll}
\hline Description & Female $(\mathrm{mm})$ & Male $(\mathrm{mm})$ \\
\hline Snout vent length & 46 & 44 \\
Length of head & 14 & 14 \\
Width of head & 17 & 16 \\
Length of snout & 6 & 6 \\
Maximum length of eye (antero-posterior) & 7 & 7 \\
Inter orbital space & 5 & 5 \\
Distance between eye and tympanum & 2 & 2 \\
Relative length of fingers & $3>1>2>4$ & $3>1>2>4$ \\
Length of Arm & 25 & 26 \\
Length of tympanum & 3 & 3 \\
Length of leg & 60 & 58 \\
Width of tibia & 5 & 5 \\
Length of tibia & 18 & 18 \\
Length of foot & 18 & 18 \\
Relative length of toes & $4>3>5>2>1$ & $4>3>5>2>1$ \\
\hline
\end{tabular}

